\title{
Seedling Growth Pattern of Guava (Psidium guajava L.) as Influenced by Different Seed Scarification Treatments
}

\author{
Sourabh*, Jeet Ram Sharma, Satpal Baloda and Vivek Beniwal
}

Dept. of Horticulture, CCS Haryana Agricultural University, Hisar, Haryana (125 004), India

\section{Corresponding Author}

Sourabh

e-mail: sourabhjakhar@hotmail.com

\author{
Article History \\ Article ID: IJEP0236 \\ Received in $29^{\text {th }}$ October, 2017 \\ Received in revised form $08^{\text {th }}$ August, 2018 \\ Accepted in final form $17^{\text {th }}$ August, 2018
}

\begin{abstract}
Plant growth studies involve seed germination studies and this depends on seed viability and dormancy aspects, besides essential requirements and factors for the same. Of the various factors involved in seed germination, dormancy plays a significant role. In guava, seed dormancy is more of physical nature (due to hard seed coat) than being physiological. An experiment was conducted from March-November, 2015 at the experimental orchard of the Department of Horticulture, CCSHAU, Hisar to study effect of different scarification treatments on guava seed germination and their effect on subsequent seedling growth.Three scarification methods were used i.e. water soaking (for 24, 48 and $72 \mathrm{hrs}$ ), hot water soaking (at 70,80, 90 and $100^{\circ} \mathrm{C}$ ) and sulphuric acid soaking (at 10, 20, 30, 40 and 50\% dilution). Duration for hot water soaking and sulphuric acid soaking was kept as quick dip ( 5 seconds), 1 minute and 3 minutes. All these treatments significantly decreased days to emergence of seedling over control. Among the various scarification methods and durations used, treatment of guava seeds with $20 \%$ sulphuric acid for 3 minutes was judged best with maximum germination per cent (51.7\%), Quick dip of guava seeds in $30 \%$ sulphuric acid resulted in better seedling growth with a maximum seedling height $(42 \mathrm{~cm})$ while maximum fresh weight of shoot $(22.6 \mathrm{~g})$ and maximum dry weight of shoot $(8.81 \mathrm{~g})$ was recorded in seedlings which were subjected to scarification treatment with quick dip at $90^{\circ} \mathrm{C}$.
\end{abstract}

Keywords: Guava, seed, scarification, seedling growth, sulphuric acid

\section{Introduction}

Guava (Psidium guajava L.), family Myrtaceae, 'The Apple of the Tropics' and 'Poor Man's Apple' is an important fruit crop of country, not only because of large area and production but due to its wider edapho-climatic adaptability, various biotic and abiotic stresses hardiness, precocious and prolific bearing habit, quality fruit with high nutritive value and medicinal attribute.Although guava is native to Central America but now it is cultivated and naturalized throughout the tropics and due to increasing demand; it is also grown in some subtropical regions. It was introduced in India in the $17^{\text {th }}$ century by Portuguese and is now being commercially cultivated in area of 268.2 thousand hectares, with the production of 3667.9 thousand MT and productivity of $13.7 \mathrm{MT} \mathrm{ha}^{-1}$ (Saxena and Gandhi, 2015).

In recent past in Haryana, area (10700 ha) and production (1.25 mt) of guava has increased substantially (Anonymous, 2014) which shows that farmers have shown an interest towards guava cultivation but have to cope with the shortage of quality propagational material. The demand is not fulfilled because of unavailability of superior seedling rootstocks which might be due to poor seed germination and seedling growth.
Guava seeds germinate poorly and unevenly and require more time for seedling emergence (Doijode, 2001). Besides, there is no standard scarification method for treatment of guava seeds. The dormancy in seeds might be due to hard seed coat and impermeability to water and gases. Soaking of seeds in water promotes germination by softening the hard seed coat, activating the enzymes and minimising the effects of inhibitors. Pandey and Singh (2000) reported 90\% germination of seeds of cultivar Allahabad Safeda by soaking in water for 36 hours before sowing. Different scarification methods like water soaking, acid scarification and chemical treatments are used for breaking dormancy in peach seeds to improve germination (Thakur and Singh,2015). Sourabh et al. (2016) reported increased seed germination in guava cultivar L- 49 by soaking in $20 \%$ sulphuric acid for 3 minutes. Acid exposure for 15 minutes resulted in $72 \%$ germination of ber seeds as it dissolved the seed coat more and made germination easier (Karimpour et al., 2013). According to Choi et al. (2016) sulphuric acid scarification is effective in breaking physical dormancy with each acid concentration has a different optimal time for different Rubus sp.

Despite, the advances in use of scarification, a little is known 
about its usage in raising guava seedlings from seed. Hence the present research work was undertaken to get acquainted with the different effects that scarification treatment brings in seed germination and subsequent seedling growth pattern of guava.

\section{Materials and Methods}

The experiment was conducted in Randomized Block Design during March-November, 2015 at the experimental orchard of the Department of Horticulture, CCS Haryana Agricultural University, Hisar. Hisar has a typical semi-arid climate with hot and dry summer and extremely cold winter. Guava seeds were collected from fully ripe fruits of L-49 variety. A total of 31 treatments replicated thrice were given to guava seeds and they were sown in nursery under uniform agronomic conditions. 100 seeds per treatments were used. Details of treatments are given below-
A. Hot water soaking:
i) $70{ }^{\circ} \mathrm{C}$
ii) $80^{\circ} \mathrm{C}$
iii) $90^{\circ} \mathrm{C}$
iv) $100^{\circ} \mathrm{C}$
B. Sulfuric acid soaking:
i) $10 \%$ solution
ii) $20 \%$ solution
iii) $30 \%$ solution
iv) $40 \%$ solution
v) $50 \%$ solution

Note: Duration of each of the above treatments under $A$ and B was kept as quick dip (5 seconds), 1 minute and 3 minutes.

C. Water soaking $(24,48$ and 72 hours)

D. Control (untreated)

Germination percentage was calculated by sowing hundred seeds of each treatment in a randomized block design (RBD) replicated three times at Experimental Orchard, Department of Horticulture, CCS Haryana Agricultural University, Hisar. The germination counts were made on the $45^{\text {th }}$ days after sowing when the germination has completely ceased and germination was expressed in percentage. The germination percentage was calculated as:

Germination $\%=\frac{\text { Number of normal seedlings }}{\text { Total number of seeds }} \times 100$

Seedling height was measured from the collar region to tip of the shoot and mean shoot length was expressed in centimetres after a time period of 60,90, 120 and 150 days after sowing. Similarly, fresh weight and dry weight of shoot was measured at 60,90, 120 and 150 days after sowing and weighed in grams. Statistical analysis of data collected during the study was done by applying the technique of analysis of variance (ANOVA) as suggested by Gomez and Gomez (1984) and Panse and Sukhatme (1961). All the statistical analysis was carried out by using OPSTAT statistical software.

\section{Results and Discussion}

\subsection{Germination (\%)}

The data on seed germination percentage depicted in Figure 1 reveals that different scarification treatments significantly

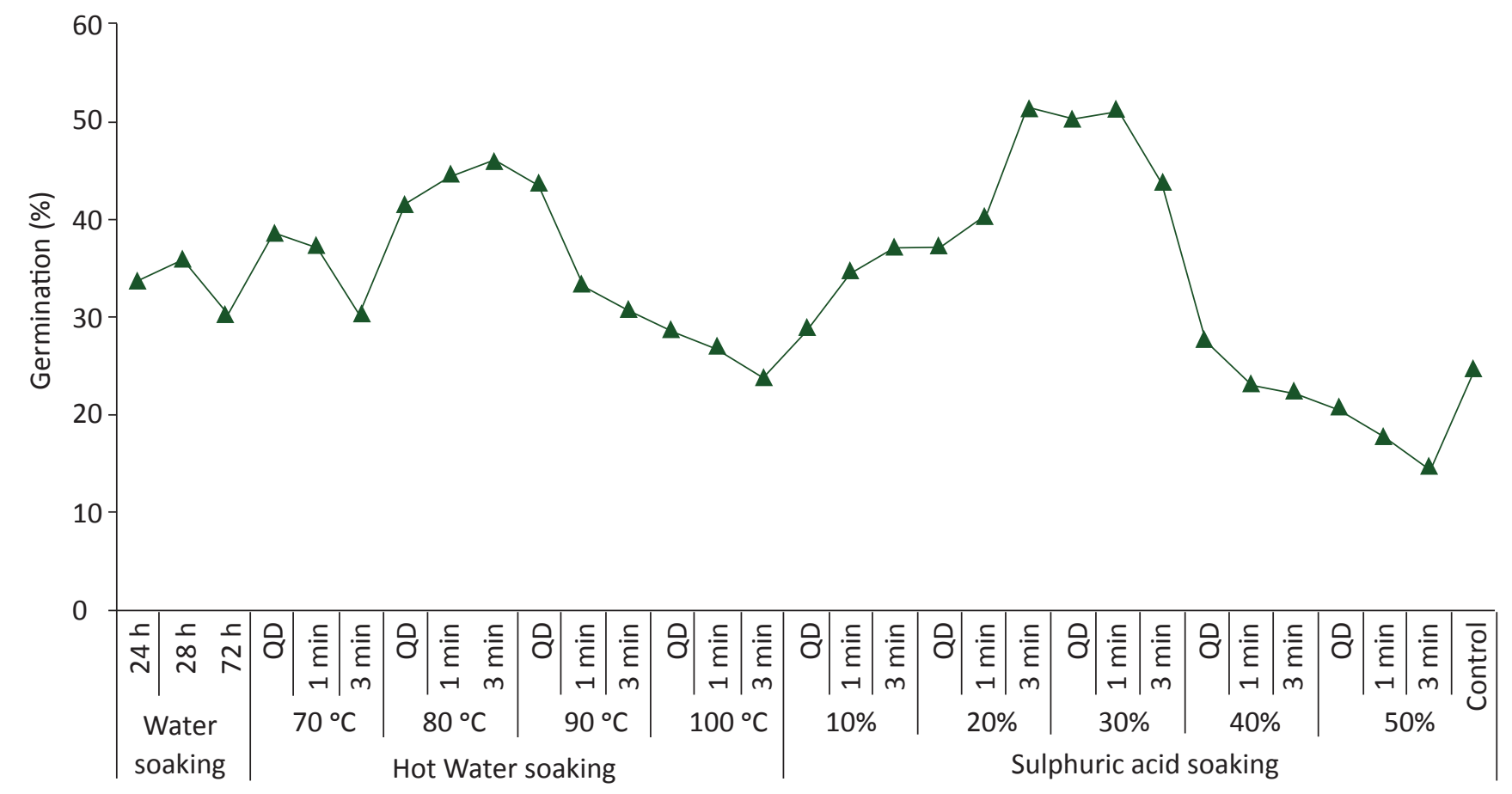

Figure 1: Effect of different scarification treatments on germination percentage 
affected the seed germinationpercentage of guava in nursery. The germination per cent varies from 14.7 and goes up to $51.7 \%$. The maximum germination $(51.7 \%)$ was recorded with 3 minute soaking in $20 \%$ sulphuric acid that was statistically at par with quick dip and 1 minute soaking in 30\% sulphuric acid ( 50.3 and $51.3 \%$, respectively).The minimum germination (14.7\%) was reported with 3 minute soaking in $50 \%$ sulphuric acid solution. Results showed that water soaking of seeds (24, 48 and $72 \mathrm{hrs}$ ) increased the germination per cent as compared to control treatment.

Similarly, quick dip and soaking of guava seeds in $70{ }^{\circ} \mathrm{C}, 80$ ${ }^{\circ} \mathrm{C}, 90{ }^{\circ} \mathrm{C}$ and $100{ }^{\circ} \mathrm{C}$ hot water also significantly increased the germination per cent except 3 minutes soaking in $100^{\circ} \mathrm{C}$ hot water where it decreased non-significantly. Quick dip and soaking of seeds in $10 \%, 20 \%$ and $30 \%$ sulphuric acid solution significantly improved the germination per cent of guava seeds over control. Quick dip in $40 \%$ sulphuric acid solution significantly increased the germination per cent, while, 1 minute soaking non-significantly decreased it as compared to control treatment. 40\% (3 minutes) and 50\% (quick dip, 1 and 3 minutes) sulphuric acid solution soaking significantly decreased the germination per cent as compared to control treatment.

This increase in germination by sulphuric acid treatment may be due to the stimulating effect of sulphuric acid which softens seed coat and allows easy permeability to air and water. These results are in close conformity with the findings of Singh and Soni (1974) and Brijwal et al. (2013) as they reported that soaking of guava seeds in sulphuric acid for 3 minutes improved the germination counts over control. Ali et al. (2007) reported higher guava seed germination (85\%) using 5 sulphuric acid for $12 \mathrm{hrs}$. They reported negative effect of increased acid concentration on seed germination which explains the lower germination percentage at higher sulphuric acid concentration. The effectiveness of boiling water treatment in enhancing germination has been attributed to the release of physical dormancy from hard seeded species by causing ruptures in the seed wall thereby allowing imbibition, oxygen diffusion and germination to occur (Egley, 1989; Maslin and McDonald, 2004; Sedbrook, 2006).

The decline of germination at higher water temperature could be attributed to embryo damage caused by wet heating (Powell, 1990) or probably due to low oxygen availability at high temperature which resulting in destruction of certain enzymatic components (Teketay, 1998). Reisman-Berman et al. (1989) reported that the decrease in germination per cent in $72 \mathrm{hrs}$ water soaking treatment may be attributed to water trapped in tissue between the embryo and seed coat creating an oxygen barrier. Moreover, Norton (1986) concluded that anoxia caused by prolonged soaking of seeds may result in irreversible injury due to accumulation of toxic metabolites hence poor germination.

\subsection{Height of guava seedling}

The effect of different scarification treatments on seedling height at 60,90, 120 and150 days after sowing is illustrated in Figure 2. The minimum $(14.6 \mathrm{~cm})$ and maximum $(42.0 \mathrm{~cm})$

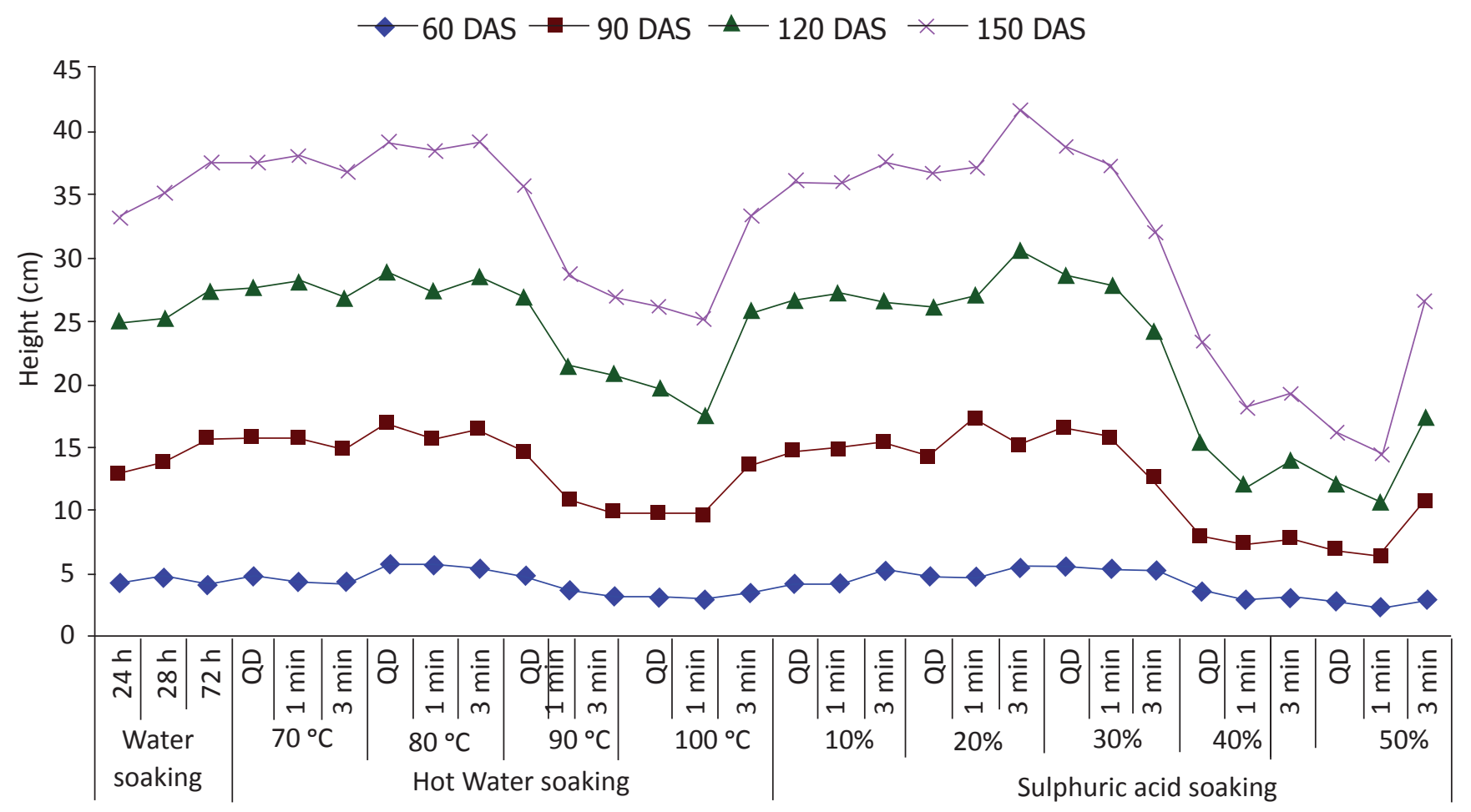

Figure 2: Effect of different scarification treatments on height of guava seedlings $(\mathrm{cm})$ 
height of seedlings was reported with treatment of 3 minutes soaking in $50 \%$ sulphuric acid solution and quick dip in $30 \%$ sulphuric acid solution, respectively. Results showed that water soaking of guava seeds significantly increased the height of seedlings over control. Similarly, quick dip and soaking of seeds in $70{ }^{\circ} \mathrm{C}, 80^{\circ} \mathrm{C}$ and $90{ }^{\circ} \mathrm{C}$ hot water also significantly increased the height of seedlings. However, effect of quick dip in $100{ }^{\circ} \mathrm{C}$ hot water was non-significant, while soaking ( 1 and 3 minute) significantly decreased the height of seedlings as compared to control.The reason behind this may be due to the corresponding number of days to emergence of seedling and mean germination time with corresponding treatments. Also, higher concentration of sulphuric acid and higher temperature damages the embryo and decreases seed vigour as reported by Abdul-Baki (1973).

\subsection{Fresh weight of Shoot}

The effect of different scarification treatments on fresh weight of shoot at $60,90,120$ and 150 days after sowing is illustrated in Table 1. The minimum ( $11.4 \mathrm{~g}$ ) fresh weight of shoot was reported with 3 minutes soaking in $50 \%$ sulphuric acid solution that was statistically at par with 1 minute soaking in 50\% sulphuric acid solution (12.1 g). The maximum fresh weight of shoot (22.6 g) was recorded with quick dip in $90^{\circ} \mathrm{C}$ hot water treatment or 1 minute soaking in $30 \%$ sulphuric acid solution that was statistically at par with quick dip in 30\%sulphuric acid (22.5 g), 3 minute soaking in $20 \%$ sulphuric acid $(22.2$ g), 1 and 3 minutes soaking in $80^{\circ} \mathrm{C}$ hot water (22.0 and 22.1 grespectively). Quick dip and soaking of seeds in $10 \%, 20 \%$ and $30 \%$ sulphuric acid solution significantly increased the fresh weight of shoot over control.

\subsection{Dry weight of Shoot}

The effect of different scarification treatments on fresh weight of shoot at 60,90, 120 and 150 days after sowing is illustrated in Table 2. The minimum (4.45 g) dry weight of shoot was reported with 3 minute soaking in $50 \%$ sulphuric acid solution. The maximum dry weight of shoot $(8.81 \mathrm{~g})$ was recorded with quick dip in $90^{\circ} \mathrm{C}$ hot water that was statistically at par with quick dip and 1 minute soaking in 30\% sulphuric acid ( 8.74 and 8.80 g respectively), 3 minute soaking in $20 \%$ sulphuric acid (8.64 g) and 1 and 3 minute soaking in $80^{\circ} \mathrm{C}$ hot water (8.55 and $8.60 \mathrm{~g}$, respectively). Results showed that water soaking (24, 48 and $72 \mathrm{hrs}$ ) of guava seeds significantly increased the dry weight of shoot as compared to control.

The maximum fresh and dry weight of shoot and roots of seedlings with sulphuric acid treatments might be due to the fact that sulphuric acid softens the seed coat allowing better permeability of air and water for better and early germination which in turn contribute to the increase in fresh and dry weight of shoot and roots of seedlings. The higher concentration of sulphuric acid and higher temperature damages the embryo and decreases seed vigour (Abdul-Baki, 1973) thus resulting in weak germination may be the reason behind the minimum fresh and dry weight of shoot and roots of seedlings with
$50 \%$ sulphuric acid treatment for 3 minutes. Similar increase and decrease in fresh and dry weight of shoot and roots of

Table 1: Effect of different scarification treatments on fresh weight of shoot (g)

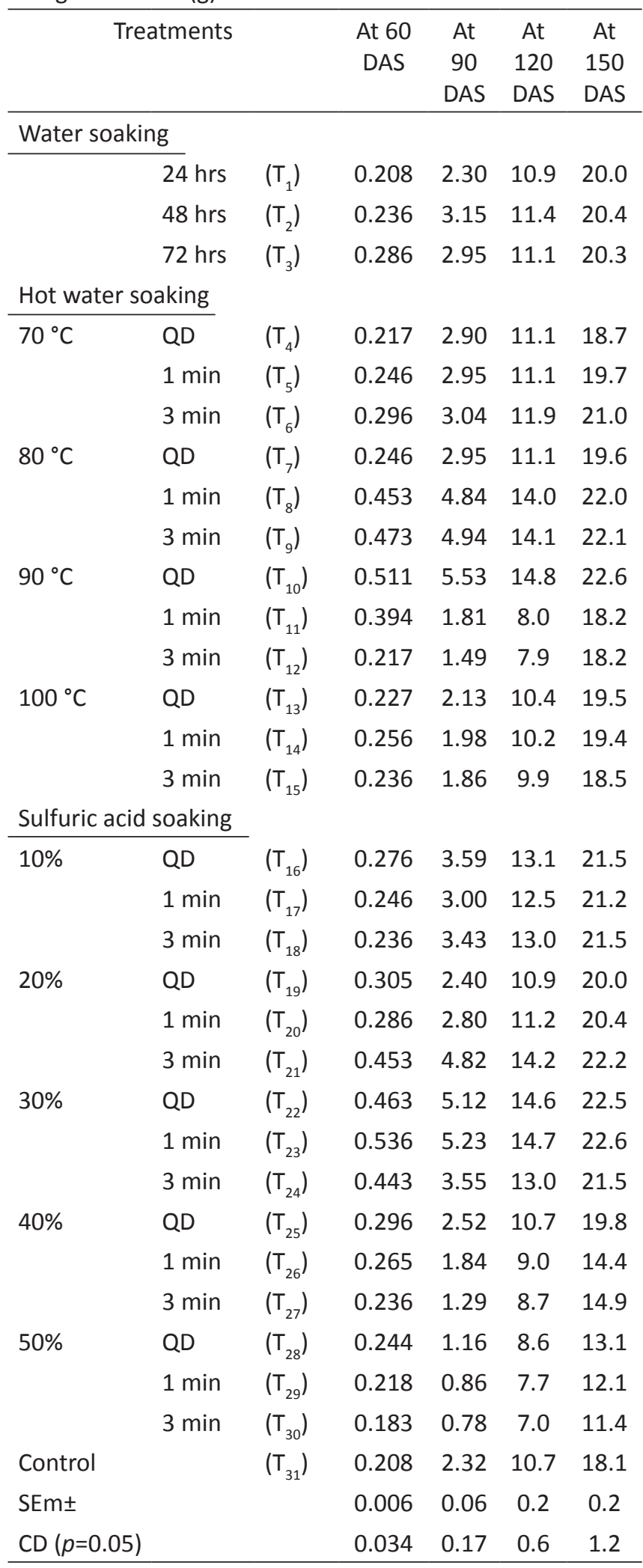




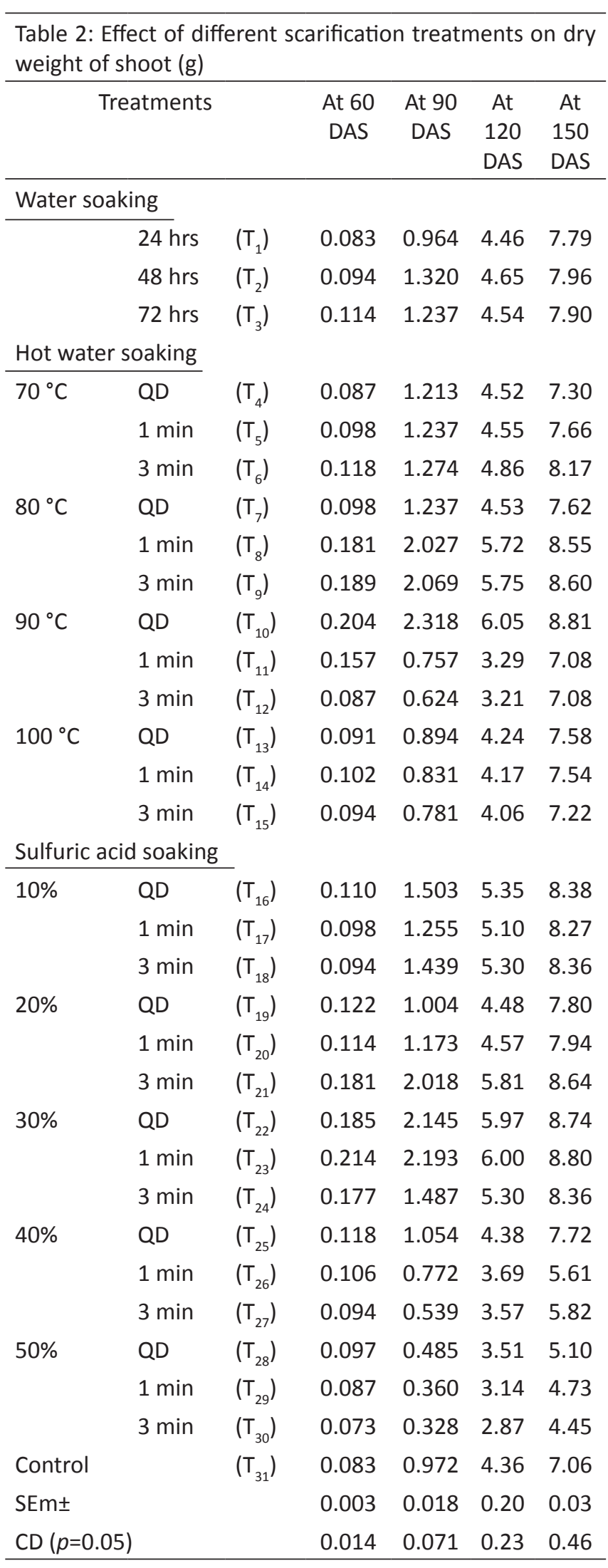

*hrs: Hours; min - Minute/s; QD: Quick dip; DAS: Days after sowing seedlings due to sulphuric acid treatments was reported by Egley (1989) in some tree species which support the present findings.

\section{Conclusion}

Scarification of guava seeds with low concentrations of sulphuric acid i.e. $20 \%$ and $30 \%$ and short duration dipping in hot water i.e. $80^{\circ} \mathrm{C}$ and $90^{\circ} \mathrm{C}$ for 5 seconds to 1 minute, results in better seed germination and healthy and vigorous seedling growth.

\section{Acknowledgement}

The authors acknowledge the CCS HAU for funding the research. The authors are also indebted to the Head of Department, Department of Horticulture, COA,CCS HAU for providing the requisite facilities for the work.

\section{References}

Abdul-Baki, A.A., Anderson, J.D., 1973. Vigour determination in soybean seed by multiple criteria. Crop Science 13, 630-632.

Ali, N., Mulwa, R.M.S., Norton, M.A., Skirvin, R.M., 2007. Radical disinfestation protocol eliminates in vitro contamination in guava (Psidium guajava L.) seeds. Plant Cell, Tissue Organ Culture 91, 295-298.

Anonymous, 2014. Indian Horticulture Database. National Horticulture Board, Gurgaon, Ministry of Agriculture, Government of India, India, 76-83.

Brijwal, M., Kumar, R., Mishra, D.S., 2013. Effect of presowing treatments on seed germination of guava (Psidium guajava L.) under tarai region ofUttarakhand. Progressive Horticulture 45(1), 154-159.

Choi, G.E., Ghimire, B., Lee, H., Jeong, M.J., Kim, H.J., Ku, J.J., Lee, K.M., Son, S.W., Lee, C.H., Park, J.I., Suh, G.U., 2016. Scarification and stratification protocols for breking dormancy of Rubus (Rosaceae) species in Korea. Seed Science and Technology 44, 239-252.

Doijode, S.D., 2001. Guava (Psidium guajava L.). Seed Storage of Horticultural Crops 21, 65-67.

Egley, G.H., 1989. Water-impermeable seed coverings as barriers to germination. In: Taylorson, R.B. (Ed.), Recent Advances in the Development and Germination of Seeds. New York, Plenum Press, 207-223.

Gomez, K.A., Gomez, A.A., 1984. Statistical Procedure for Agricultural Research (2 ${ }^{\text {nd }}$ Edn.), John Wiley and Sons, New York, USA.

Karimpour, S., Davarynejad, G.H., Rouhbakhsh, H.,Ardakani, E., 2013. Data on scarification and stratification treatments on germination and seedling growth of Ziziphus jujube seeds. Advances in Environmental Biology 7(3), 501-505.

Maslin, B.R., McDonald, M.W., 2004. Acacia search-evaluation of Acacia as a woody crop option for southern Australia. Rural Industries Research Development Corporation Publication No. 03/017, Canberra. 
Norton, C.R., 1986. Germination under flooding: Metabolic implications and alleviation of injury. Horticultural Science. 21, 1123-1125.

Pandey, D., Singh, H.P., 2000. Effect of seed pretreatmenton promotion of germination in guava. Annals of Agricultural Research 21, 279-281.

Panse, V.G., Sukatme, P.V., 1961. Statistical methods for agricultural workers. Indian Council of Agricultural Research, New Delhi, 155.

Powell, R.,1990. Leaf and Branch: Trees and Tall Shrubs of Perth. Perth, Western Australia: Department of Conservation and Land Management. ISBN 0-73093916-2.

Reisman-Berman, O., Kigel, J., Rubin, B., 1989. Short soaking in water inhibits germination of Daturaferox and $D$. stramonium L. seeds. Weed Research 29, 357-363.

Saxena, M., Gandhi, C.P., 2014. Indian Horticulture Database. National Horticulture Board, Gurgaon, Ministry of
Agriculture, Government of India.

Sedbrook, J., 2006. Gardening and Horticulture. Denver County Cooperative Extension. Available from http://www. colostate.edu /Depts /CoopExt/4DMG/Glossary/s.htm.

Singh, S.,Soni, S.L., 1974. Effect of water and acid soaking periods on seed germination in guava. Punjab Horticultural Journal14(3-4), 122-124.

Sourabh, Sharma, J.R.,Baloda, S., 2016. Effect of scarification treatments on seed germination of guava (Psidium guajava L.) under south-western region of Haryana. The EcoscanIX, 409-414.

Teketay, D.,1998. Germination of Acacia origena, A. pilispina and Pterolobium stellatumin response to different presowing seed treatments, temperature and light. Journal of Arid Environment 38, 551-560.

Thakur, B., Singh, H., 2015. Studies on seed germination in peach (Prunus persica (L.) Batsch) rootstock 'Flordaguard'. The Bioscan 10(2), 651-654. 